Discussion Paper No. 01-68

Economic Impacts of a Premature Nuclear Phase-Out in Switzerland

Christoph Böhringer, Marcel Wickart, and André Müller

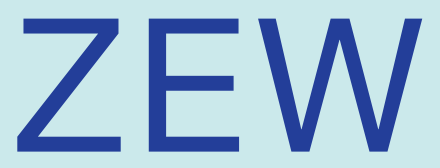

Zentrum für Europäische Wirtschaftsforschung GmbH

Centre for European Economic Research 
Discussion Paper No. 01-68

\title{
Economic Impacts of a Premature Nuclear Phase-Out in Switzerland
}

\author{
Christoph Böhringer, Marcel Wickart, and André Müller
}

Download this ZEW Discussion Paper from our ftp server:

ftp://ftp.zew.de/pub/zew-docs/dp/dp0168.pdf

Die Discussion Papers dienen einer möglichst schnellen Verbreitung von neueren Forschungsarbeiten des ZEW. Die Beiträge liegen in alleiniger Verantwortung der Autoren und stellen nicht notwendigerweise die Meinung des ZEW dar.

Discussion Papers are intended to make results of ZEW research promptly available to other economists in order to encourage discussion and suggestions for revisions. The authors are solely responsible for the contents which do not necessarily represent the opinion of the ZEW. 


\section{Non-technical summary:}

This paper investigates the economic impacts of two policy proposals: "Strom ohne Atom" $(S O A)$ and "Moratorium Plus" (MOP), both of which contain a premature phase-out of nuclear power in Switzerland. While MOP restricts business-as-usual operation time of existing nuclear power plants to 40 years, which results in a cutback of 10-20 years, SOA foresees a reduction in operation time of 20-30 years and administers combined heat and power to substitute for nuclear energy. Based on simulations with an intertemporal multisector general equilibrium model of the Swiss economy, we find that SOA, particularly, imposes non-negligible adjustment costs to the Swiss economy. The reason is that SOA - as compared to $M O P$-is not only more restrictive with respect to the permissible operation time of existing nuclear power plants; it also administers the use of non-competitive CHP during the transition phase to back up nuclear capacities. Costs of accelerating the phase-out of nuclear power for an average household amount to $200 \mathrm{CHF} / \mathrm{a}$ over the next 45 years under $S O A$ and drop to $60 \mathrm{CHF} / \mathrm{a}$ in the case of MOP. Under climate policy considerations, both phase-out scenarios induce substantially higher carbon emissions during the adjustment path, since larger $B A U$ supplies of carbon-free nuclear power must be replaced by fossil fuel technologies. If Switzerland were to keep carbon emissions at $B A U$ levels larger $\mathrm{CO}_{2}$ taxes would have to be levied, which would magnify the costs of a premature phase-out. In the case of carbon-neutrality, adjustment costs increase to $230 \mathrm{CHF}$ under SOA (i.e. SOA-N) and 110 CHF under $M O P$ (i.e. $M O P-N$ ). In our calculations we do not account for the external costs of nuclear power due to the large uncertainties in the valuation of nuclear risks. Therefore, the adjustment costs presented in our analysis can not be interpreted as simple excess costs of energy policy interference, but must be viewed as the price tag for the risk reduction from nuclear power operation given additional constraints (preferences) on back-up technologies and carbon neutrality. 


\title{
Economic Impacts of a Premature Nuclear Phase-Out in Switzerland
}

An applied general equilibrium analysis

\author{
Christoph Böhringer \\ Zentrum für Europäische Wirtschaftsforschung (ZEW), Mannheim \\ boehringer@zew.de \\ André Müller \\ Ecoplan, Bern \\ mueller@ecoplan.ch \\ Marcel Wickart \\ Ecoplan, Bern \\ wickart@ecoplan.ch \\ December 2001
}

\begin{abstract}
This paper investigates the economic impacts of two policy proposals: "Strom ohne Atom" (SOA) and "Moratorium Plus" (MOP), both of which contain a premature phase-out of nuclear power in Switzerland. While $M O P$ restricts business-as-usual operation time of existing nuclear power plants to 40 years, which results in a cutback of 10-20 years, SOA foresees a reduction in operation time of 2030 years and administers combined heat and power to substitute for nuclear energy. Based on simulations with an intertemporal multi-sector general equilibrium model of the Swiss economy, we quantify the price tags for risk reduction from nuclear power operation given additional constraints on back-up technologies. Costs of accelerating the phase-out of nuclear power for an average household amount to $200 \mathrm{CHF} / \mathrm{a}$ over the next 45 years under SOA and drop to $60 \mathrm{CHF} / \mathrm{a}$ in the case of MOP. If Switzerland were to assure carbon neutrality of a premature phase-out by the use of carbon taxes, adjustment costs would increase to $230 \mathrm{CHF}$ under SOA and $110 \mathrm{CHF}$ under MOP.
\end{abstract}

Keywords: nuclear phase-out, computable general equilibrium

JEL-classification: Q48, C68 


\section{Introduction}

In 2002, the Swiss voters will have to decide on two proposals for a premature phase-out of nuclear power in Switzerland, which currently accounts for $40 \%$ of the Swiss electricity production. Both proposals foresee a reduction of the operating time of existing nuclear power plants as compared to business-as-usual $(B A U)$. Under $B A U$ the power plants are scheduled to be in operation for 50 up to 60 calendar years. The proposal "Strom ohne Atom" (SOA) postulates a maximum operating time of 30 year, whereas the proposal "Moratorium Plus" (MOP) restricts the operating time to 40 years. SOA is not only more restrictive with respect to the permissible operating time but also entails the massive promotion of non-competitive combined heat and power to substitute for nuclear power.

In this paper, we investigate the economic implications induced by the premature phase-out scenarios of nuclear power under SOA and MOP. The main insights from our analysis can be summarized as follows:

- SOA induces non-negligible adjustment costs for the Swiss economy with an annual loss of 200 CHF per year and household over the next 45 years. This amount may be interpreted as a required average willingness-to-pay for having the SOA proposal implemented.

- The negative repercussions of $S O A$ get substantially attenuated in the $M O P$ scenario. Not only the use of existing nuclear power capacities for additional ten years but also the unrestricted choice of non-nuclear replacement technologies cut down aggregate adjustment costs vis-à-vis $S O A$. Instead of the administered use of combined heat and power under $S O A$, cheaper combined cycle gas turbines will back up nuclear power in the MOP scenario. At the household level, average costs drop to $60 \mathrm{CHF} / \mathrm{a}$.

- The premature phase-out of nuclear power increases Swiss $\mathrm{CO}_{2}$ emissions, since fossil fuel power generation will be used more extensively than under $B A U$. To assure carbon neutrality with respect to $B A U$ emission levels, carbon taxes of up to $45 \mathrm{CHF}$ per ton of $\mathrm{CO}_{2}$ must be imposed under $S O A$ and $M O P$. The tax-induced distortions magnify the phase-out costs. Annual losses per household over the next 45 years increase to $230 \mathrm{CHF}$ for the case of SOA and $110 \mathrm{CHF}$ for the case of $M O P$.

- Economy-wide employment losses of premature nuclear phase-out are negligible, since substitution effects in factor demand of sectoral production compensate negative output effects. Even for the case of carbon neutrality, where carbon taxes reduce labor productivity, recycling of tax revenues through cuts in labor costs nearly offset negative impacts on labor demand.

Our results are based on simulations with an intertemporal computable general equilibrium (CGE) model for the Swiss economy. An important feature of this model is the incorporation of a bottom-up engineering-type representation of the electricity sector within an aggregate top-down description of the rest of the economy. This hybrid approach (see Böhringer 1996 and 1998 for the 
general methodology) accounts for discrete technological responses in the power sector that will be triggered by energy policy interference.

There are two previous studies which investigated the potential economic effects of SOA and MOP (Prognos 2000; Pfaffenberger and Gerdey 2001). Both studies are based on bottom-up partial equilibrium models for the Swiss electricity sector. Hence, these studies only capture the direct effects of energy policy interference on the electricity sector and do not report indirect effects on indicators of the remaining economy. In addition, they do not account for forward-looking behavior of economic agents which may substantially flaw economic rationality of investment decisions in the context of long-term policy issues. A comparison of cost estimates reveals that the bottom-up studies might significantly underestimate the economy-wide costs of a premature phase-out since negative feed-back and spillover effects to other markets are neglected.

The remainder of this paper is as follows. Section 2 provides a non-technical summary of the model and its parameterization. Section 3 lays out the policy scenarios and the simulation results. Section 4 concludes.

\section{Analytical Framework}

Our model combines several features that are required for an appropriate quantitative simulation of the effects induced by exogenous energy policy measures:

- At the sectoral level, it incorporates sufficient detail on sector-specific differences in factor intensities, degrees of input substitutability and price elasticites of demand in order to trace back the structural change in production and consumption patterns induced by a policy shift.

- The Swiss tax system is represented in sufficient detail to capture initial tax distortions.

- Consumption and investment decisions are based on rational expectations of future prices (clairvoyance). This assures that the effects of policy interference on savings and investments are consistently taken into account.

- Capital is internationally mobile with the rates of return determined by an exogenous international interest rate.

- The production possibilities in the electricity sector are represented by the convex combinations of discrete technological options instead of top-down smooth constant-elasticityof substitution (CES) production functions usually employed within the CGE approach. The bottom-up description of technologies for the electricity sector, which is based on engineering data, provides a realistic picture of endogenous adjustment to policy measures that are, particularly, targeted to the electricity sector (as is the case for nuclear phase-out policies).

The following section provides a non-technical description of an intertemporal multi-sector computable general equilibrium (CGE) model designed for the analysis of energy policy interference 
in open economies. The detailed algebraic model formulation can be downloaded from www.ecoplan.ch/download/swiss_phase_out_app.pdf.

\subsection{Basic Model Structure}

The model contains a disaggregate representation of 38 industries, whereby the electricity sector is modeled in technological detail. To account for different pollutant and energy intensities as well as inter-fuel substitution possibilities across energy goods, the model identifies 6 energy goods: heavy oil, light oil, gasoline, diesel, gas and electricity. Furthermore, the model incorporates major electricity-intensive industries such as the textile industry or manufacturing of paper which are most susceptible to the effects of changes in electricity prices. Producer goods are directly demanded by government, investment and export. Producer goods for consumption are demanded only indirectly because the model distinguishes 13 aggregate consumption categories which are produced by combining the outputs of the 38 industries in fixed proportions. Tables A1 and A2 in the appendix summarize the classification of industry and consumer commodities.

\section{Production}

Competitive entrepreneurs minimize the cost of production and allocate investment across sectors in order to maximize the present value of firms. For each industry except for the electricity sector, an aggregate production function characterizes technology through transformation possibilities on the output side (between production for domestic and export markets) and substitution possibilities on the input side (between alternative combinations of inputs). On the output side, production is split between goods produced for the domestic market and goods produced for the export market subject to a constant elasticity of transformation. On the input side, nested separable CES functions describe the technological substitution possibilities in domestic production between capital, labor, energy and material inputs (including diesel and gasoline). At the top level, material inputs are used in fixed proportions, together with a CES aggregate of labor and an energy-capital composite. Within the latter energy-capital composite, energy and capital trade off at a constant elasticity of substitution. The energy aggregate, in turn, is produced with a CES technology using oil (heavy and light oil), gas and electricity as inputs.

\section{Household Behavior}

Consumers choose to allocate lifetime income across consumption in different time periods. In each period, the consumer faces the choice between current consumption (non-leisure consumption goods and leisure) and savings (future consumption). The pure rate of time preference determines the intertemporal allocation of consumption. We employ a separable intertemporal utility function where the intra-period utility from consumption is based on a nested CES function over leisure and nonleisure consumption commodities. Utility from different periods trade off at a constant intertemporal elasticity of substitution. 


\section{Factors}

Primary factors of production are labor and capital. Labor supply is elastic. Capital and labor are inter-sectorally mobile in the home country, but only capital can move across domestic borders. Total labor endowment increases with labor force efficiency along a steady-state growth rate. Capital stocks evolve through geometric depreciation and new investment. In the small open economy framework, the rates of return on mobile capital are determined by the international interest rate. We assume perfectly competitive factor markets in which factor prices adjust so that supply equals demand.

\section{Government Sector}

The government distributes transfers and provides a public good (including public investment), which is produced with commodities purchased at market prices. Government expenditures are financed with tax revenues. The model incorporates the main features of the Swiss tax and social transfer system. The public budget is balanced on an intertemporal basis. Along the baseline growth path, public income and expenditures balance on a period-by-period basis. In the policy counterfactuals, the application of environmental taxes might result in a temporary public deficit, as the anticipation of future tax revenue permits public expenditure to exceed government income during the initial periods. In all simulations the present value of public expenditure equals the present value of tax revenues.

\section{Investment and Savings}

The level of savings is endogenously determined by households which maximize lifetime consumption over the time horizon. Firm owners choose investment in order to maximize the present value of the firm. Investors and households compete for current consumption such that in equilibrium the marginal utilities of savings (future consumption) and demand (current consumption) are equalized.

\section{Foreign Trade}

Following the proposition of Armington (1969), domestic and foreign goods are distinguished by origin. This accommodates both imports and exports of the same commodity to reflect empirical evidence on the crosshauling of trade flows. Due to lack of more detailed data, domestic and imported varieties of the same good are aggregated with identical shares across all components of final and intermediate demand. Demand for imports stems from cost-minimizing producer behavior and utility maximization of households. On the export side, products destined for domestic and international markets are treated as imperfect substitutes, which trade off at a constant rate of substitution. Switzerland is treated as small in relation to the world market. The small country assumption implies that changes in the level of Swiss exports and imports have no effect on its terms of trade international prices are exogenously fixed in foreign currency, i.e. export demand and import supply functions are horizontal. International capital flows (borrowing and lending) are endogenous, subject to an intertemporal balance of payments constraint, i.e. there is no change in net indebtedness over the 
model horizon. The imposition of an intertemporally balanced trade account is linked to a variable exchange rate which reconciles the present value of domestic import and foreign export demands.

\subsection{Parameterization of the Basic Model}

As is customary in applied general equilibrium analysis, the model is based on economic transactions in a benchmark year, 1998 in our case. Benchmark data determines parameters of the functional forms from a given set of benchmark quantities, prices, and elasticities. We replace the aggregate input-output monetary values for energy supply and demand with physical energy flows supplemented by official energy prices for industry and households (for details, see Prognos 1996). Data on various tax payments and transfers are taken from the Swiss Statistical Yearbook 1998. Consistency of the intertemporal model with steady-state growth implies an endogenous relationship between three parameters: the rate of time preference, the depreciation rate of capital, and the growth rate of labor in efficiency units. In our simulations, we assume an exogenous labor growth rate of $1.3 \%$ and a time preference rate (interest rate) of $2 \%$, which yields a capital depreciation rate of $4 \%$. Tables A3 and A4 in the appendix summarize key elasticities.

\subsection{Bottom-up Representation of Electricity Sector}

\section{Overview of Electricity Sector Sub-Module}

The standard description of power generation options via nested CES functions is replaced with a discrete representation of technologies (Böhringer 1998). Power producers have discrete choices with respect to alternative technologies and combine these base on capacity constraints in order to meet electricity demand in a cost-minimizing way. Swiss power generation in the base year is represented through eight technologies which cover the five nuclear power plants KKB I (Beznau I), KKB II (Beznau II), KKM (Mühleberg), KKG (Gösgen) and KKL (Leibstad), a representative hydro power technology, a representative combined heat and power (CHP) technology, and a conventional oil-fired power plant technology.

Table 1 provides a summary of base-year technologies, incorporated in the electricity sub-module of our model, with the respective shares in total Swiss electricity production.

Table 1: Overview of base-year power generation technologies

\begin{tabular}{|c|c|c|c|c|c|c|c|c|c|}
\hline & \multicolumn{5}{|c|}{ Nuclear power plants } & \multirow{2}{*}{$\begin{array}{l}\text { Hydroelectric } \\
\text { power plants }\end{array}$} & \multirow{2}{*}{ CHP } & \multirow{2}{*}{$\begin{array}{c}\text { Oil fired } \\
\text { power plants }\end{array}$} & \multirow{2}{*}{ Total } \\
\hline & KKB I & KKB II & KKM & KKG & KKL & & & & \\
\hline \multirow{2}{*}{ GWh } & 2736 & 2676 & 2682 & 7640 & 8527 & \multirow{2}{*}{33200} & \multirow{2}{*}{1622} & \multirow{2}{*}{1098} & \multirow{2}{*}{60181} \\
\hline & & & 24261 & & & & & & \\
\hline Share & $4.6 \%$ & $4.5 \%$ & $\begin{array}{r}4.5 \% \\
40.5 \%\end{array}$ & $12.7 \%$ & $14.2 \%$ & $55.17 \%$ & $2.70 \%$ & $1.82 \%$ & $100 \%$ \\
\hline
\end{tabular}

As to replacement technologies, there are three different combined cycle gas turbines (CCGT) technologies, one district heating technology (DH) and eight different CHP technologies that differ with respect to cost structure and potential production capacities. 
Electricity is routed to consumers via three different types of grids: supraregional, regional, and local grids. The respective end customers face different distribution prices. As to regional and supraregional grids, a further price distinction is made between major customers and average customers. The total price for electricity is composed of uniform electricity generation prices and consumer-specific distribution prices. Furthermore, the model distinguishes between winter load and summer load. Each power generation technology is characterized by an annual load pattern. Figure 1 sketches the structure of the electricity sector as incorporated into the general equilibrium model.

\section{Figure 1: Modeling of electricity sector}

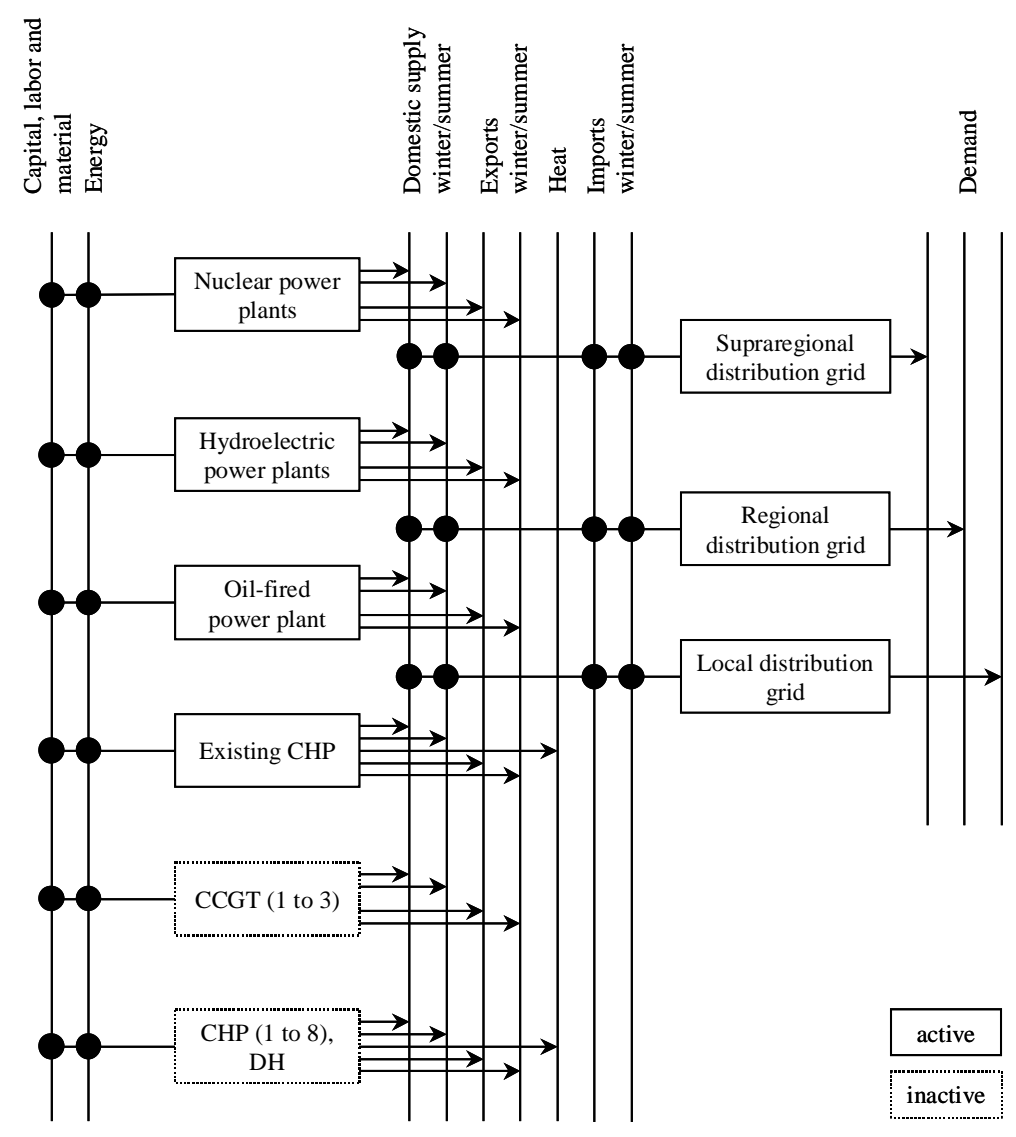

\section{Parameterization}

For the economic analysis of premature nuclear phase-out policies, the marginal costs of existing power plants as well as the full cost of backup technologies are crucial. Tables 2 and 3 provide the main economic indicators for existing Swiss power plants as well as future replacement options (for details see Ecoplan 2001 pp. 125). Backup technologies include three different combined cycle gas turbines (CCGT), district heating (DH), and eight combined heat and power technologies (CHP). Technologies not only differ with respect to cost structure but also with respect to capacity bounds. 
Table 2: Economic indicators of existing power plants technologies

\begin{tabular}{|c|c|c|c|c|c|c|}
\hline \multicolumn{7}{|c|}{ Nuclear power plants } \\
\hline & KKB I & \multicolumn{2}{|c|}{ KKB II } & KKM & KKG & KKL \\
\hline Production potential $(\mathrm{GWh} / \mathrm{a})$ & 2736 & \multicolumn{2}{|c|}{2676} & 2682 & 7639 & 8527 \\
\hline Winter share $(\%)$ & 56.8 & \multicolumn{2}{|c|}{56.8} & 56.8 & 56.8 & 56.8 \\
\hline Operation costs (Cts./kWh) & \multirow{2}{*}{\multicolumn{4}{|c|}{2.52}} & & \\
\hline Maintenance and labor costs & & & & & 1.71 & 1.69 \\
\hline Disposal costs & \multicolumn{4}{|c|}{0.26} & 0.26 & 0.26 \\
\hline Fuel costs & \multicolumn{4}{|c|}{0.65} & 0.59 & 0.5 \\
\hline Total $($ Cts./kWh) & \multicolumn{4}{|c|}{3.43} & 2.57 & 2.46 \\
\hline Costs for extending operating time +10 years & \multicolumn{4}{|c|}{0.74} & 0.71 & 0.75 \\
\hline Total - extended lifetime (Cts./kWh) & \multicolumn{4}{|c|}{4.17} & 3.28 & 3.20 \\
\hline \multicolumn{7}{|c|}{ Existing non-nuclear power plants } \\
\hline & \multicolumn{2}{|c|}{$\begin{array}{c}\text { Hydroelectric } \\
\text { power plants }\end{array}$} & & $\begin{array}{l}\text { sting CHP } \\
\text { plants }\end{array}$ & \multicolumn{2}{|c|}{$\begin{array}{l}\text { Oil fired power } \\
\text { plants }\end{array}$} \\
\hline Production potential $(\mathrm{GWh} / \mathrm{a})$ & \multicolumn{2}{|c|}{33200} & & 1622 & \multicolumn{2}{|c|}{1098} \\
\hline Winter share $(\%)$ & \multicolumn{2}{|c|}{44.8} & & 64.6 & \multicolumn{2}{|c|}{53.2} \\
\hline Operation costs (Cts./kWh) & \multirow{4}{*}{\multicolumn{2}{|c|}{3.40}} & & & \multirow{2}{*}{\multicolumn{2}{|c|}{1.25}} \\
\hline Maintenance and labor costs & & & & 1.24 & & \\
\hline Fuel costs & & & & 6.05 & \multicolumn{2}{|c|}{3.75} \\
\hline ./. Heat credit & & & & 2.81 & & \\
\hline Capital costs & \multicolumn{2}{|c|}{2.77} & & 1.88 & \multicolumn{2}{|c|}{1.25} \\
\hline Total (Cts./kWh) & \multicolumn{2}{|c|}{6.17} & & 6.36 & \multicolumn{2}{|c|}{6.25} \\
\hline
\end{tabular}

Table 3: Economic indicators of backup technology options

\begin{tabular}{|c|c|c|c|c|c|c|c|}
\hline & 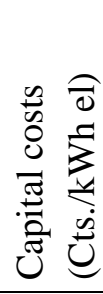 & 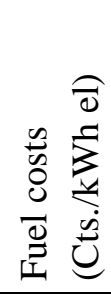 & 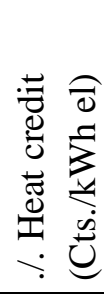 & 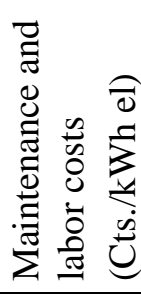 & 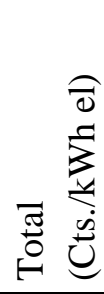 & 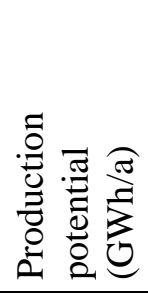 & 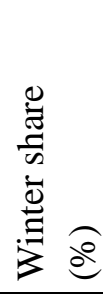 \\
\hline CCGT1 & 0.79 & 4.91 & 0.00 & 0.61 & 6.30 & 1206 & 57 \\
\hline CCGT2 & 0.99 & 4.91 & 0.00 & 0.76 & 6.65 & 135 & 71 \\
\hline CCGT3 & 1.39 & 4.91 & 0.00 & 1.07 & 7.36 & & 100 \\
\hline DH & 1.72 & 5.52 & 2.57 & 1.14 & 5.81 & 1206 & 75 \\
\hline CHP1 & 1.58 & 9.16 & 4.84 & 1.21 & 7.12 & 135 & 55 \\
\hline CHP2 & 1.82 & 7.07 & 3.87 & 2.31 & 7.33 & 855 & 75 \\
\hline CHP3 & 1.95 & 7.56 & 4.19 & 2.48 & 7.80 & 866 & 75 \\
\hline CHP4 & 1.59 & 10.32 & 5.27 & 1.27 & 7.91 & 350 & 55 \\
\hline CHP5 & 2.59 & 8.51 & 4.94 & 2.67 & 8.83 & 940 & 74 \\
\hline CHP6 & 3.42 & 9.88 & 5.93 & 2.78 & 10.15 & 1339 & 75 \\
\hline CHP7 & 3.57 & 11.81 & 7.30 & 3.13 & 11.22 & 971 & 80 \\
\hline CHP8 & 4.11 & 12.67 & 7.88 & 3.33 & 12.23 & $>1000$ & 80 \\
\hline
\end{tabular}




\section{Scenarios and Results}

\subsection{Scenarios}

The economic impacts of a premature phase-out under $S O A$ and $M O P$ are measured with respect to the business-as-usual scenario $B A U$ where existing nuclear power plants remain in operation for 50 years (KKB I and II, KKM) and 60 years respectively (KKG and KKL). Moreover, under BAU as under $M O P$ no restriction is imposed on the use of power generation from fossil fuels. The scenario $M O P$ reduces operating time of nuclear power plants to 40 calendar years. The scenario SOA postulates an operating time of only 30 years and, in addition, includes the promotion of noncompetitive combined heat-and-power technologies.

Table 4 summarizes the final operating years of Swiss nuclear power plants under $B A U, M O P$ and $S O A$.

Table 4: Final operating years of Swiss nuclear power plants

\begin{tabular}{l|ccccc}
\hline & KKB I & KKB II & KKM & KKG & KKL \\
\hline BAU & 2019 & 2021 & 2022 & 2039 & 2044 \\
SOA & 2004 & 2004 & 2004 & 2009 & 2014 \\
MOP & 2009 & 2011 & 2012 & 2019 & 2024 \\
\hline
\end{tabular}

One concern of the protagonists for the premature phase-out of nuclear power is that discarded domestic nuclear power will be replaced by additional electricity imports from abroad (which may stem to a larger extent from foreign nuclear power production). In this vein, the simulations of SOA and $M O P$ assume "trade-neutrality" with respect to $B A U$. In concrete terms, we impose the $B A U$ imports as an upper bound on the permissible inflows of electricity from abroad (see Table 5). The international electricity prices applying to long-term import and export obligations are set to 5.5 Cts./kWh, which reflects long-term marginal production costs in Europe for base load.

Table 5: Upper bounds on electricity imports

\begin{tabular}{l|lll}
\hline & Total per year & Summer & Winter \\
\hline Until 2004 & 15588 & 7293 & 8295 \\
2005 till 2009 & 14828 & 6968 & 7860 \\
2010 till 2019 & 14040 & 6574 & 7466 \\
From 2020 onwards & 13900 & 6255 & 7645 \\
\hline
\end{tabular}

In addition to these import restrictions, SOA postulates that replacement capacities for nuclear power must be based on CHP. In our simulations we adopt the recommendations of the energy policy advisory board to the Swiss Federal Office of Energy (see Prognos 1999) to subsidize non-competitive CHP to a level that prevents investment in CCGT technologies during the transition period until 2045. The associated subsidies are covered by a sales tax on nuclear power, hydropower and imported electricity. 
Without further regulation, the premature nuclear phase-out will increase Swiss carbon emissions over the next decades since carbon-free nuclear power will be replaced by electricity from either CHP or CCGT, both requiring fossil fuel inputs. Given the importance of anthropogenic carbon emissions in the context of national and international greenhouse gas abatement policies, we have defined two additional scenarios $S O A-N$ and $M O P-N$, which assures $\mathrm{CO}_{2}$-neutrality as compared to $B A U$. In other words, the scenarios SOA-N and $M O P-N$ are supplemented with an economy-wide carbon constraint such that $\mathrm{CO}_{2}$ emissions do not exceed the $B A U$ emission levels. When the carbon constraint becomes binding, the associated shadow price indicates the level of the carbon tax that must be levied to warrant $\mathrm{CO}_{2}$-neutrality. Revenues from carbon taxes are recycled in proportion to tax payments through per-capita transfers to households and through a reduction in payroll taxes of employees. Table 6 provides a short characterization of all scenarios simulated in the following section.

Table 6: Summary of scenarios

\begin{tabular}{l|ccc}
\hline Scenario & $\begin{array}{c}\text { Operating time of nuclear } \\
\text { power plants }\end{array}$ & $\mathrm{CO}_{2}$ neutrality & $\begin{array}{c}\text { Fossil power generation without } \\
\text { waste heat utilization }\end{array}$ \\
\hline$B A U$ & $50 / 60$ & -- & yes \\
$S O A$ & 30 & no & no \\
$M O P$ & 40 & no & yes \\
$S O A-N$ & 30 & yes & no \\
$M O P-N$ & 40 & yes & yes \\
\hline
\end{tabular}

\subsection{Results}

Macroeconomic Impacts

Table 7 to Table 10 summarize the changes in key macroeconomic indicators across scenarios $S O A, S O A-N, M O P$, and MOP-N as compared to BAU.

Table 7: Macroeconomic impacts of $S O A$ (in \% change versus $B A U$ )

\begin{tabular}{l|c|c|c|c|c|c|c|c}
\hline & 2005 & 2010 & 2015 & 2020 & 2025 & 2030 & 2035 & long run \\
\hline GDP & $-0.15 \%$ & $-0.32 \%$ & $-0.56 \%$ & $-0.57 \%$ & $-0.55 \%$ & $-0.54 \%$ & $-0.53 \%$ & $-0.27 \%$ \\
Domestic production & $-0.09 \%$ & $-0.20 \%$ & $-0.32 \%$ & $-0.34 \%$ & $-0.33 \%$ & $-0.33 \%$ & $-0.34 \%$ & $-0.21 \%$ \\
Labor input & $-0.03 \%$ & $-0.12 \%$ & $-0.15 \%$ & $-0.16 \%$ & $-0.14 \%$ & $-0.13 \%$ & $-0.13 \%$ & $-0.07 \%$ \\
Capital input & $-0.05 \%$ & $-0.14 \%$ & $-0.24 \%$ & $-0.35 \%$ & $-0.42 \%$ & $-0.45 \%$ & $-0.47 \%$ & $-0.34 \%$ \\
Consumption & $-0.06 \%$ & $-0.15 \%$ & $-0.28 \%$ & $-0.33 \%$ & $-0.35 \%$ & $-0.36 \%$ & $-0.37 \%$ & $-0.15 \%$ \\
Investments & $-0.87 \%$ & $-1.23 \%$ & $-1.65 \%$ & $-1.48 \%$ & $-1.29 \%$ & $-1.22 \%$ & $-1.18 \%$ & $-0.68 \%$ \\
\hline Energy use & $0.18 \%$ & $0.42 \%$ & $2.86 \%$ & $3.19 \%$ & $3.52 \%$ & $3.89 \%$ & $3.77 \%$ & $-0.25 \%$ \\
Electricity & $0.25 \%$ & $-4.33 \%$ & $-8.65 \%$ & $-8.55 \%$ & $-8.02 \%$ & $-7.48 \%$ & $-7.10 \%$ & $-0.24 \%$ \\
Fossil energy & $0.16 \%$ & $2.27 \%$ & $7.44 \%$ & $7.99 \%$ & $8.29 \%$ & $8.61 \%$ & $8.14 \%$ & $-0.25 \%$ \\
\hline Real wage & $-0.10 \%$ & $-0.21 \%$ & $-0.32 \%$ & $-0.34 \%$ & $-0.33 \%$ & $-0.33 \%$ & $-0.34 \%$ & $-0.17 \%$ \\
Real capital rate & $-0.11 \%$ & $-0.22 \%$ & $-0.33 \%$ & $-0.36 \%$ & $-0.34 \%$ & $-0.34 \%$ & $-0.35 \%$ & $-0.19 \%$ \\
\hline
\end{tabular}


Table 8: Macroeconomic impacts of $M O P$ (in \% change versus $B A U$ )

\begin{tabular}{l|c|c|c|c|c|c|c|c}
\hline & 2005 & 2010 & 2015 & 2020 & 2025 & 2030 & 2035 & long run \\
\hline GDP & $0.05 \%$ & $0.06 \%$ & $0.05 \%$ & $-0.01 \%$ & $-0.06 \%$ & $-0.07 \%$ & $-0.08 \%$ & $-0.01 \%$ \\
Domestic production & $0.03 \%$ & $0.04 \%$ & $0.02 \%$ & $0.02 \%$ & $0.04 \%$ & $0.01 \%$ & $0.00 \%$ & $-0.03 \%$ \\
Labor input & $0.02 \%$ & $0.02 \%$ & $0.01 \%$ & $-0.01 \%$ & $-0.01 \%$ & $-0.02 \%$ & $-0.02 \%$ & $-0.03 \%$ \\
Capital input & $0.01 \%$ & $0.03 \%$ & $0.04 \%$ & $0.03 \%$ & $0.02 \%$ & $-0.01 \%$ & $-0.04 \%$ & $-0.08 \%$ \\
Consumption & $-0.04 \%$ & $-0.05 \%$ & $-0.05 \%$ & $-0.07 \%$ & $-0.09 \%$ & $-0.09 \%$ & $-0.08 \%$ & $-0.02 \%$ \\
Investment & $0.29 \%$ & $0.27 \%$ & $0.17 \%$ & $0.04 \%$ & $-0.04 \%$ & $-0.07 \%$ & $-0.17 \%$ & $0.04 \%$ \\
\hline Energy use & $-0.01 \%$ & $0.07 \%$ & $0.28 \%$ & $3.83 \%$ & $8.63 \%$ & $7.58 \%$ & $7.92 \%$ & $-0.05 \%$ \\
Electricity & $-0.01 \%$ & $0.15 \%$ & $0.60 \%$ & $-0.98 \%$ & $-1.36 \%$ & $-1.28 \%$ & $-0.23 \%$ & $-0.05 \%$ \\
Fossil energy & $-0.01 \%$ & $0.03 \%$ & $0.15 \%$ & $5.79 \%$ & $12.76 \%$ & $11.26 \%$ & $11.19 \%$ & $-0.05 \%$ \\
\hline Real wage & $0.02 \%$ & $0.02 \%$ & $0.01 \%$ & $-0.02 \%$ & $-0.02 \%$ & $-0.03 \%$ & $-0.04 \%$ & $0.00 \%$ \\
Real capital rate & $0.01 \%$ & $0.00 \%$ & $-0.01 \%$ & $-0.04 \%$ & $-0.04 \%$ & $-0.05 \%$ & $-0.06 \%$ & $-0.02 \%$ \\
\hline
\end{tabular}

Table 9: Macroeconomic impacts of $S O A-N$ (in \% change versus $B A U$ )

\begin{tabular}{l|c|c|c|c|c|c|c|c}
\hline & 2005 & 2010 & 2015 & 2020 & 2025 & 2030 & 2035 & long run \\
\hline GDP & $-0.27 \%$ & $-0.46 \%$ & $-0.71 \%$ & $-0.73 \%$ & $-0.71 \%$ & $-0.69 \%$ & $-0.67 \%$ & $-0.38 \%$ \\
Domestic production & $-0.15 \%$ & $-0.34 \%$ & $-0.59 \%$ & $-0.62 \%$ & $-0.60 \%$ & $-0.58 \%$ & $-0.56 \%$ & $-0.25 \%$ \\
Labor input & $-0.05 \%$ & $-0.17 \%$ & $-0.20 \%$ & $-0.20 \%$ & $-0.18 \%$ & $-0.17 \%$ & $-0.14 \%$ & $-0.06 \%$ \\
Capital input & $-0.07 \%$ & $-0.21 \%$ & $-0.35 \%$ & $-0.48 \%$ & $-0.54 \%$ & $-0.57 \%$ & $-0.57 \%$ & $-0.37 \%$ \\
Consumption & $-0.03 \%$ & $-0.15 \%$ & $-0.30 \%$ & $-0.37 \%$ & $-0.40 \%$ & $-0.43 \%$ & $-0.44 \%$ & $-0.17 \%$ \\
Investment & $-1.49 \%$ & $-1.93 \%$ & $-2.37 \%$ & $-2.19 \%$ & $-1.96 \%$ & $-1.80 \%$ & $-1.66 \%$ & $-1.06 \%$ \\
\hline Energy use & $0.19 \%$ & $-1.10 \%$ & $-1.09 \%$ & $-1.32 \%$ & $-1.27 \%$ & $-0.97 \%$ & $-0.58 \%$ & $-0.27 \%$ \\
Electricity & $0.25 \%$ & $-4.90 \%$ & $-8.66 \%$ & $-9.10 \%$ & $-9.10 \%$ & $-8.81 \%$ & $-7.95 \%$ & $-0.26 \%$ \\
Fossil energy & $0.17 \%$ & $0.39 \%$ & $1.93 \%$ & $1.86 \%$ & $1.97 \%$ & $2.29 \%$ & $2.38 \%$ & $-0.27 \%$ \\
\hline Real wage & $-0.13 \%$ & $-0.27 \%$ & $-0.34 \%$ & $-0.38 \%$ & $-0.38 \%$ & $-0.39 \%$ & $-0.38 \%$ & $-0.23 \%$ \\
Real capital rate & $-0.12 \%$ & $-0.26 \%$ & $-0.33 \%$ & $-0.37 \%$ & $-0.38 \%$ & $-0.38 \%$ & $-0.37 \%$ & $-0.23 \%$ \\
\hline
\end{tabular}

Table 10: Macroeconomic impacts of $M O P-N$ (in \% change versus $B A U$ )

\begin{tabular}{l|c|c|c|c|c|c|c|c}
\hline & 2005 & 2010 & 2015 & 2020 & 2025 & 2030 & 2035 & long run \\
\hline GDP & $-0.04 \%$ & $-0.06 \%$ & $-0.10 \%$ & $-0.19 \%$ & $-0.27 \%$ & $-0.27 \%$ & $-0.26 \%$ & $-0.12 \%$ \\
Domestic production & $-0.02 \%$ & $-0.04 \%$ & $-0.09 \%$ & $-0.23 \%$ & $-0.36 \%$ & $-0.35 \%$ & $-0.33 \%$ & $-0.10 \%$ \\
Labor input & $-0.01 \%$ & $-0.02 \%$ & $-0.05 \%$ & $-0.12 \%$ & $-0.14 \%$ & $-0.13 \%$ & $-0.10 \%$ & $-0.04 \%$ \\
Capital input & $-0.01 \%$ & $-0.03 \%$ & $-0.07 \%$ & $-0.14 \%$ & $-0.20 \%$ & $-0.23 \%$ & $-0.25 \%$ & $-0.16 \%$ \\
Consumption & $-0.02 \%$ & $-0.02 \%$ & $-0.03 \%$ & $-0.09 \%$ & $-0.17 \%$ & $-0.20 \%$ & $-0.22 \%$ & $-0.07 \%$ \\
Investment & $-0.19 \%$ & $-0.31 \%$ & $-0.56 \%$ & $-0.81 \%$ & $-0.87 \%$ & $-0.76 \%$ & $-0.67 \%$ & $-0.29 \%$ \\
\hline Energy use & $0.00 \%$ & $0.05 \%$ & $0.24 \%$ & $-0.03 \%$ & $-0.86 \%$ & $-0.65 \%$ & $-0.10 \%$ & $-0.12 \%$ \\
Electricity & $0.00 \%$ & $0.13 \%$ & $0.55 \%$ & $-2.69 \%$ & $-5.10 \%$ & $-5.03 \%$ & $-4.08 \%$ & $-0.11 \%$ \\
Fossil energy & $-0.01 \%$ & $0.02 \%$ & $0.12 \%$ & $1.05 \%$ & $0.90 \%$ & $1.17 \%$ & $1.49 \%$ & $-0.12 \%$ \\
\hline Real wage & $-0.02 \%$ & $-0.04 \%$ & $-0.07 \%$ & $-0.12 \%$ & $-0.14 \%$ & $-0.16 \%$ & $-0.15 \%$ & $-0.08 \%$ \\
Real capital rate & $-0.02 \%$ & $-0.03 \%$ & $-0.07 \%$ & $-0.12 \%$ & $-0.14 \%$ & $-0.16 \%$ & $-0.15 \%$ & $-0.08 \%$ \\
\hline
\end{tabular}

We start interpretation of results for scenarios $S O A$ and $M O P$, which do not impose CO2neutrality. GDP - as a key indicator of economic performance drops to $0.57 \%$ under SOA $(0.08 \%$ for $M O P)$ during the transition period and remains $0.27 \%(0.01 \%$ in the case of $M O P)$ below $B A U$ levels 
in the long-run. The premature nuclear phase-out implies a loss of productive resources, i.e. the use of existing nuclear capacities for electricity generation. Earlier investment in replacement technologies leads to a rise in electricity prices that increase production costs with negative impacts on electricity demand and sectoral output during the adjustment period. In the long run, consumption and investment grow from a slightly smaller level. Clearly, the magnitude of these effects is determined by the effective reduction of nuclear power generation as compared to $B A U$. The shorter the permissible operation time of power plants vis-à-vis $B A U$ is, the higher the induced negative adjustment effects are.

Table 8 indicates that the economy-wide impacts of $M O P$ are insignificant, whereas $S O A$ induces non-negligible adjustment costs. Only a share of the cost differences is attributable to the difference in calendar year reduction. The main reason for the substantially higher adjustment costs under $S O A$ as compared to $M O P$ is the administered use of rather expensive CHP until 2045 to back up nuclear capacities, whereas under $M O P$, rather cheap combined cycle-gas turbines (CCGT) can be used. The implied cost-differences are reflected in the magnitude of electricity price increases and the associated declines in electricity demand (see Figure 2 and 3). Under SOA, the transitional increase in electricity price is much higher than under $M O P$, causing a larger decline in electricity demand. Fossil fuel use in both scenarios rises as compared to $B A U$ because nuclear power is replaced by gas powered CCGT or CHP. The increase in fuel demand under SOA is lower than under MOP because of lower overall electricity demand. In the long run, the structure of power production under SOA and MOP nearly coincides with $B A U$ because the runtime restrictions for nuclear power plants become obsolete and the same power plant replacement options become available.

Figure 2: Electricity price index in $S O A$ and $M O P$ (in \% change versus $B A U$ )

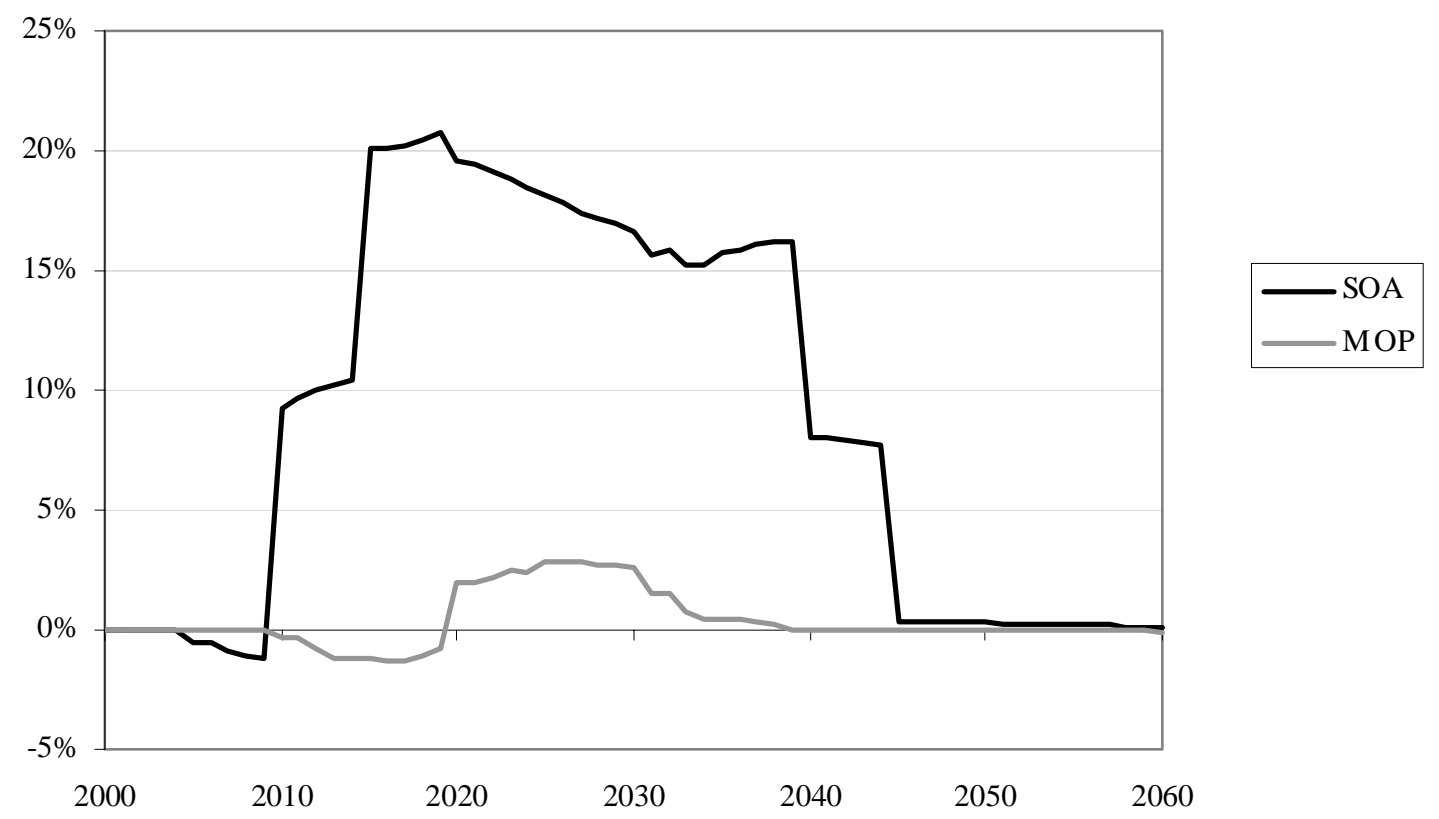


Figure 3: Electricity consumption in $S O A$ and $M O P$ (in \% change versus $B A U$ )

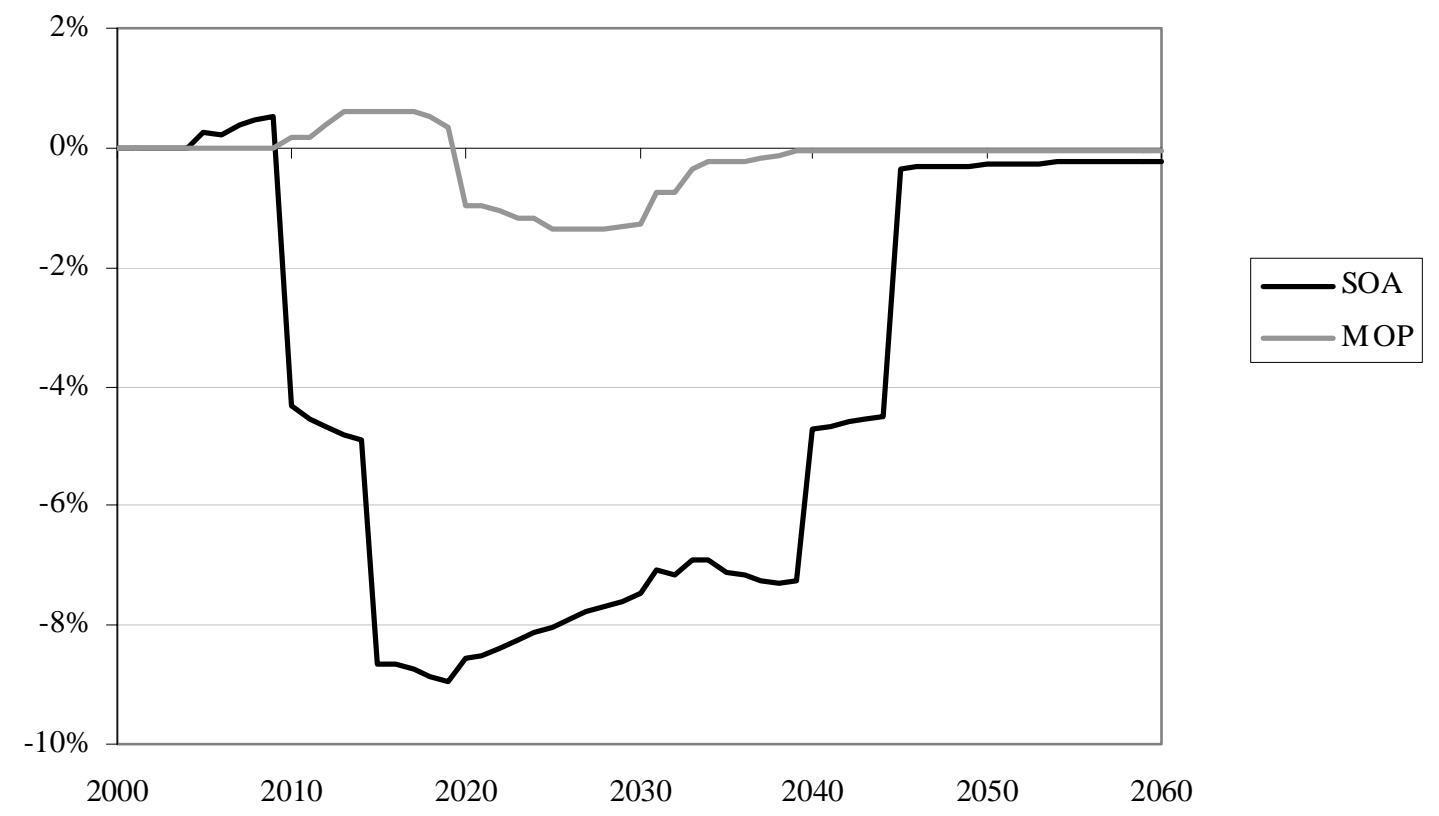

Comparison of Tables 9 and 10 with Tables 7 and 8 reveals that the imposition of carbon taxes to assure $\mathrm{CO}_{2}$-neutrality magnifies the costs of a premature nuclear phase-out. On the adjustment path, GDP losses range up to $0.73 \%$ under $S O A-N(0.27 \%$ for $M O P-N)$ and fall $0.38 \%(0.12 \%$ in the case of $M O P-N$ ) short of the long-run $B A U$ values. The reason for this is that carbon taxes, which are levied up to $\mathrm{CHF} 45$ per ton of $\mathrm{CO}_{2}$ during the transition period, decrease factor productivity and, hence, real income. The revenue-neutral cuts of payroll taxes cannot fully offset the downward pressure of carbon taxes on the real wage such that the drop in real wages is more pronounced than for scenarios SOA and $M O P$ without carbon neutrality. Decreased capital productivity joined with higher costs of producing the investment goods leads to a further drop in the rate of return, which implies lower levels of investment and reduced capital stocks. The long-term decrease in real consumption can be traced back to the decline in real income.

In all four scenarios, employment losses are negligible. Significant repercussions on labor demand which could have been triggered by carbon taxes are to a larger extent offset by revenueneutral cuts in labor costs. Negative impacts on labor demand, due to the decline in production, are compensated by factor substitution effects as labor becomes relatively cheaper compared to capital inputs.

\section{Welfare}

The welfare implications of the phase-out scenarios can be measured in terms of Hicksian equivalent variation in lifetime income (HEV). For example, a HEV of minus $1 \%$ indicates a loss in lifetime income of $1 \%$ as compared to the $B A U$. For the sake of transparency, we have converted the HEV for the four policy counterfactuals into equivalent annual costs per average Swiss household over the transition period between 2000-2045 (see Table 11). This number indicates how many CHF per 
year the household foregoes due to the respective phase-out scenario. It can be interpreted as the required average willingness-to-pay of a Swiss citizen to see the respective proposals in place.

Table 11: Welfare implications (projected on the period 2000 - 2045)

\begin{tabular}{l|c}
\hline & CHF per year (CHF/a) and average Swiss household \\
\hline SOA & -200 \\
SOA-N & -230 \\
$M O P$ & -60 \\
$M O P-N$ & -110 \\
\hline
\end{tabular}

SOA imposes costs of $200 \mathrm{CHF} / \mathrm{a}$, whereas costs under MOP only amount to $60 \mathrm{CHF} / \mathrm{a}$. Under carbon neutrality, the cost for both cases increase due to the distortionary effects of the additional carbon taxes.

Sectoral Output

Figure 4: Impact of $S O A$ on production in electricity-intensive sectors (in \% change versus $B A U$ )

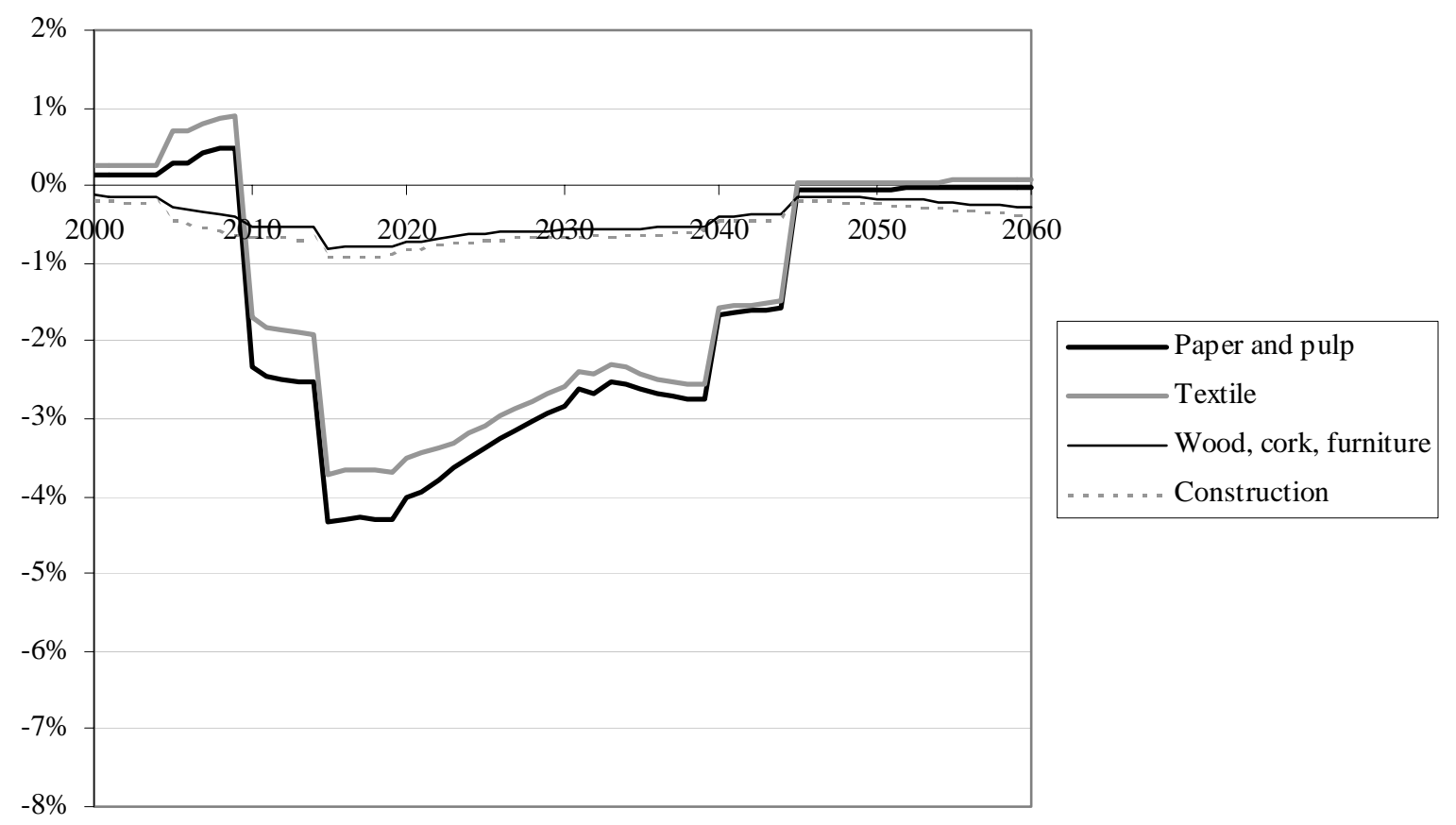

The long-term impacts of a premature nuclear phase-out on sectoral production are negligible; in all four scenarios the long-term deviations from $B A U$ levels are less than $0.5 \%$. An accelerated phaseout induces some structural change during the transition period but in the long run $S O A$ and $M O P$ are no longer constrained vis-à-vis $B A U$ which explains the very similar long-term structure. Only under $S O A$ and $S O A-N$ with their substantial increase in electricity prices, do electricity-intensive sectors such as textiles or paper face a significant decline in output due to the increase of production cost during the transition period. Figure 4 illustrates the impacts of $S O A$ on production in selected electricity-intensive sectors (under $S O A-N$ the effects are only slightly higher, since increased energy 
costs in these sectors are more or less offset by cutbacks in labor costs). In line with the electricity price changes, the production in textile and wood drops by more than $4 \%$ in 2015 but recovers during the adjustment process to catch up with $B A U$ levels in the long run.

\section{Conclusions}

In this paper, we have investigated the economic implications of a premature nuclear phase-out in Switzerland. Our simulations have been based on two concrete policy proposals - SOA and MOP which will decided upon by the Swiss voters in 2002. The quantitative results show that SOA, particularly, imposes non-negligible adjustment costs to the Swiss economy. The reason is that SOAas compared to $M O P$-is not only more restrictive with respect to the permissible operation time of existing nuclear power plants; it also administers the use of non-competitive CHP during the transition phase to back up nuclear capacities. Costs of accelerating the phase-out of nuclear power for an average household amount to $200 \mathrm{CHF} / \mathrm{a}$ over the next 45 years under $S O A$ and drop to $60 \mathrm{CHF} / \mathrm{a}$ in the case of $M O P$.

Under climate policy considerations, both phase-out scenarios induce substantially higher carbon emissions during the adjustment path, since larger $B A U$ supplies of carbon-free nuclear power must be replaced by fossil fuel technologies. If Switzerland were to keep carbon emissions at $B A U$ levels larger $\mathrm{CO}_{2}$ taxes would have to be levied, which would magnify the costs of a premature phase-out. In the case of carbon-neutrality, adjustment costs increase to $230 \mathrm{CHF}$ under $S O A$ (i.e. $S O A-N$ ) and $110 \mathrm{CHF}$ under $M O P$ (i.e. $M O P-N)$.

We have not accounted for the external costs of nuclear power in our calculations due to the large uncertainties in the valuation of nuclear risks. Therefore, the adjustment costs presented in our analysis can not be interpreted as simple excess costs of energy policy interference, but must be viewed as the price tag for the risk reduction from nuclear power operation given additional constraints (preferences) on back-up technologies and carbon neutrality. 


\section{References}

Armington, P.S. (1969): A Theory of Demand for Producers Distinguished by Place of Production, IMF Staff Papers 16, 159-178.

Böhringer, C. (1996): Allgemeine Gleichgewichtsmodelle als Instrument der energie- und umweltpolitischen Analyse - Theoretische Grundlagen und empirische Anwendung, Peter Lang: Europäischer Verlag der Wissenschaften, Stuttgart.

Böhringer, C. (1998): The Synthesis of Bottom-Up and Top-Down in Energy Policy Modeling, Energy Economics 20, 233-248.

Ecoplan (2001): Wirtschaftliche Auswirkungen der Volksinitiativen "Strom ohne Atom" und "MoratoriumPlus", commissioned by the Swiss Federal Office of Energy, Bern.

Pfaffenberger, W. und H.-J. Gerdey (2001): Volkswirtschaftliche Auswirkungen des Ausstiegs der Schweiz aus der Kernenergie, commissioned by Unterausschuss Kernenergie der Überlandwerke, Bremen.

Prognos (1996): Energieperspektiven der Szenarien I bis III, 1990 - 2030, Synthesebericht, commissioned by the Swiss Federal Office of Energy, Bern.

Prognos (1999): Szenario zur Entwicklung ausgewählter Energiepreise in der Schweiz, commissioned by the Swiss Federal Office of Energy, Bern.

Prognos (2000): Szenarien zu den Initiativen „Strom ohne Atom“ sowie „Moratorium plus“, commissioned by the Swiss Federal Office of Energy, Bern. 


\section{Appendix}

Table A1: Overview of production sectors

\begin{tabular}{|c|c|c|}
\hline ID & Sector & ASWZ* \\
\hline AGR & Agriculture, hunting, forestry and fishing & 0 \\
\hline ELE & Electricity & 111 \\
\hline GAS & Gas & 112 \\
\hline WAS & Water supply & 113 \\
\hline $\mathrm{NAH}$ & Manufacture of food products & 21 \\
\hline GET & Manufacture of beverages & 22 \\
\hline $\mathrm{TAB}$ & Manufacture of tobacco products & 23 \\
\hline TEX & Manufacture of textiles & 24 wo. 2414 \\
\hline KLE & Manufacture of wearing apparel, dressing and dyeing of fur & 25 \\
\hline HOL & Manufacture of products of wood, cork and furniture & 26 \\
\hline SAE & Manufacture of wood & 261 \\
\hline PAP & Manufacture of paper and paper products & 27 \\
\hline GRA & Publishing, printing and reproduction of recorded media & 28 \\
\hline LED & Tanning and dressing of leather, and manufacture of luggage & 29 \\
\hline $\mathrm{CHE}$ & Manufacture of chemicals and chemical products & 31,2414 \\
\hline OEL & Refined petroleum products & 314 \\
\hline PLA & Manufacture of rubber and plastic products & 32 \\
\hline NME & $\begin{array}{l}\text { Manufacture other non-metallic mineral products, mining and } \\
\text { quarrying }\end{array}$ & $33,121,123$ \\
\hline MET & Manufacture of basic metals and fabricated metal products & 34 \\
\hline MFB & Manufacture of machinery, equipment and vehicles & 35 \\
\hline ETE & Manufacture of office, accounting and electrical machinery & $36,37,38$ \\
\hline BAU & Construction & 41 \\
\hline AUS & Installation and interior works & 42 \\
\hline GRO & Wholesale trade, repairing cars & $\begin{array}{l}51-531,532, \\
54\end{array}$ \\
\hline DET & Retail trade & 55,56 \\
\hline HOT & Hotels and restaurants & 57 \\
\hline EIS & Railroad transport, cable and rack railways & 61 \\
\hline TRA & Other transport and transport via pipelines & $62,63,64,65$ \\
\hline TEL & Post and telecommunications & 66 \\
\hline BAN & Financial intermediation except insurance and pension funding & 71 \\
\hline VER & Insurance and pension funding except compulsory social security & 72 \\
\hline IMO & Real estate activities (incl. leasing of real estate) & 73 \\
\hline $\mathrm{CON}$ & Renting of equipment and other business activities, repair & $\begin{array}{l}74-76,84,85, \\
87\end{array}$ \\
\hline STU & Research and development, education, and social work & $81,82,88$ \\
\hline GES & Health work & 83 \\
\hline HAU & Private households, non-profit organizations & 86,89 \\
\hline STA & Public administration and defense & 91 \\
\hline SOZ & Compulsory social security & 92 \\
\hline
\end{tabular}


Table A2: Overview of consumption categories

\begin{tabular}{ll}
\hline ID & Consumption category \\
\hline KNAH & Food \\
KGET & Semi-luxury \\
KKLW & Clothes, Furniture, Cleaning \\
KWON & Rents \\
KELE & Electricity \\
KHEI & Oil and gas \\
KGES & Health care \\
KAUT & Cars \\
KBEN & Fuel \\
KPTR & Public transport \\
KFRE & Education, recreation \\
KDIV & Other goods and services \\
KFOR & Expenditures abroad \\
\hline
\end{tabular}

Table A3: Overview of key substitution elasticities

\begin{tabular}{|c|c|c|}
\hline Substitution elasticity & Description & Value \\
\hline$\sigma^{\mathrm{KLEM}}$ & $\begin{array}{l}\text { Substitution elasticity between material aggregate } \\
\text { and labor-capital-energy composite }\end{array}$ & 0.00 \\
\hline$\sigma^{\mathrm{M}}$ & $\begin{array}{l}\text { Substitution elasticity between material inputs } \\
\text { (including diesel and gasoline) }\end{array}$ & 0.00 \\
\hline$\sigma^{\mathrm{KLE}}$ & $\begin{array}{l}\text { Substitution elasticity between labor and capital- } \\
\text { energy composite }\end{array}$ & see Table A4 \\
\hline$\sigma^{\mathrm{KE}}$ & $\begin{array}{l}\text { Substitution elasticity between capital and energy } \\
\text { composite }\end{array}$ & 0.20 \\
\hline$\sigma^{\mathrm{E}}$ & Substitution elasticity between energy inputs & 0.25 \\
\hline$\sigma^{\mathrm{EXP}}$ & $\begin{array}{l}\text { Transformation elasticity between domestic supply } \\
\text { and exports }\end{array}$ & see Table A4 \\
\hline$\sigma^{\mathrm{ARM}}$ & Armington substitution elasticity & see Table A4 \\
\hline$\sigma^{\mathrm{LEIS}}$ & $\begin{array}{l}\text { Substitution elasticity between leisure and } \\
\text { consumption composite }\end{array}$ & 1.67 \\
\hline$\sigma^{\mathrm{THO}}$ & $\begin{array}{l}\text { Substitution elasticity between transport composite, } \\
\text { heating and other consumption goods }\end{array}$ & 0.80 \\
\hline$\sigma^{\mathrm{T}}$ & Substitution elasticity between KPTR and KBEN & 0.20 \\
\hline$\sigma^{\mathrm{H}}$ & Substitution elasticity between KHEI and KELE & 0.60 \\
\hline$\sigma^{\mathrm{O}}$ & $\begin{array}{l}\text { Substitution elasticity between other consumption } \\
\text { goods }\end{array}$ & 1.00 \\
\hline$\sigma$ & Intertemporal substitution elasticity & 0.50 \\
\hline
\end{tabular}


Table A4: Values of sector-specific substitution elasticities

\begin{tabular}{|c|c|c|c|}
\hline Sector & $\sigma^{\mathrm{KLE}}$ & $\sigma^{\mathrm{EXP}}$ & $\sigma^{\mathrm{ARM}}$ \\
\hline AGR & 0.68 & 2.00 & 1.50 \\
\hline GAS & 0.80 & 2.00 & 1.50 \\
\hline WAS & 0.80 & 2.00 & 1.50 \\
\hline NAH & 0.71 & 2.00 & 1.50 \\
\hline GET & 0.71 & 2.00 & 1.50 \\
\hline TAB & 0.71 & 2.00 & 1.50 \\
\hline TEX & 0.90 & 2.00 & 2.00 \\
\hline KLE & 0.90 & 2.00 & 2.00 \\
\hline $\mathrm{HOL}$ & 0.74 & 2.00 & 2.00 \\
\hline SAE & 0.74 & 2.00 & 2.00 \\
\hline PAP & 0.74 & 2.00 & 3.50 \\
\hline GRA & 0.74 & 2.00 & 2.00 \\
\hline LED & 0.90 & 2.00 & 1.50 \\
\hline $\mathrm{CHE}$ & 0.96 & 2.00 & 1.00 \\
\hline OEL & 0.96 & 2.00 & 1.50 \\
\hline PLA & 0.74 & 2.00 & 1.00 \\
\hline NME & 0.74 & 2.00 & 5.00 \\
\hline MET & 0.74 & 2.00 & 3.00 \\
\hline MFB & 0.74 & 2.00 & 1.50 \\
\hline ETE & 0.74 & 2.00 & 1.50 \\
\hline BAU & 0.80 & 2.00 & 1.50 \\
\hline AUS & 0.80 & 2.00 & 1.50 \\
\hline GRO & 0.80 & 1.50 & 1.50 \\
\hline DET & 0.80 & $\square .50$ & 1.50 \\
\hline HOT & 0.80 & 1.50 & 1.50 \\
\hline EIS & 0.80 & 1.50 & 1.50 \\
\hline TRA & 0.80 & 1.50 & 1.50 \\
\hline TEL & 0.80 & 1.50 & 1.50 \\
\hline BAN & 0.80 & 1.50 & 1.50 \\
\hline VER & 0.80 & 1.50 & 1.50 \\
\hline IMO & 0.80 & 1.50 & 1.50 \\
\hline $\mathrm{CON}$ & 0.80 & 1.50 & 1.50 \\
\hline STU & 0.80 & 1.50 & 1.50 \\
\hline GES & 0.80 & 1.50 & 1.50 \\
\hline HAU & 0.80 & 1.50 & 1.50 \\
\hline STA & 0.80 & 1.50 & 1.50 \\
\hline SOZ & 0.80 & 1.50 & 1.50 \\
\hline
\end{tabular}

